\title{
Development and performance evaluation of a maize roaster
}

\author{
Ilori Titus Adeyinka ${ }^{1}$, Raji Abuduganiyu Olayinka ${ }^{2}$, Adejumo Akinfoye Oyime ${ }^{1}$, \\ Kilanko Oluwaseun ${ }^{3}$
}

${ }^{1}$ Dept. of Agric. Engineering Programme, Federal College of Agric, Ibadan

${ }^{2}$ Dept. of Agric. and Environmental Engineering, University of Ibadan, Ibadan

${ }^{3}$ Dept. of Mechanical Engineering, Covenant University, Ota

\section{Email address:}

iloritaa@yahoo.com (Ilori T. A.)

\section{To cite this article:}

Ilori Titus Adeyinka, Raji Abuduganiyu Olayinka, Adejumo Akinfoye Oyime, Kilanko Oluwaseun. Development and Performance Evaluation of a Maize Roaster. International Journal of Science, Technology and Society. Vol. 2, No. 5, 2014, pp. 161-164. doi: 10.11648/j.ijsts.20140205.19

\begin{abstract}
The economic situation in most developing countries have left farmers and processors operating at small scale, hence the use of automated and electric power driven equipment is limited to the few large scale processors. A maize roaster with treadle drive blower was developed, by calculating to specification each machine element, using locally sourced materials and various fabrication techniques. The maize roaster was evaluated for performance by recording time of maize roasting on four charcoal tray with different partner of air flow duct using completely randomize design and Duncan multiple range test. The result of evaluation showed that tray with semicircular pipe shape air flow duct is the most efficient and effective since it has mean time of roasting of 499.83 seconds compare with tray with direct faced shape air flow duct that has mean time of 536.75 seconds, tray with double cone shape air flow duct with mean 553.08 seconds and tray with single cone shape air flow duct which has mean of 694.58 seconds in accordance with Duncan multiple range test as efficiency increases with decrease in mean separation.
\end{abstract}

Keywords: Maize Roaster, Charcoal Tray, Time of Roasting, Air Flow Duct

\section{Introduction}

Roasting is the process by which a product, basically agricultural products, is exposed to dry heat in an oven or over a fire for the purpose of removing moisture and cooking of the products suitable for consumption. Maize when roasted gives a palatable taste and love to be consumed by both young and old.[1]Ayatse et al., (1983) studied the effect of roasting on chemical composition of maize and reported that there was no significant difference in the proximate analysis between raw and roasted maize. However, significant differences were obtained in ether extract, crude protein except moisture content and elementary composition (potassium and calcium), vitamins $\mathrm{B}_{1}$ and vitamins $\mathrm{B}_{2}$. In handling and processing of agricultural products roasting plays a vital and important role. Roasting as applied to maize must have started some hundred years ago [2] and [3]. Traditionally, maize with its husk is thrown directly into a fire and removed after the cob may have been burnt. But with modern technology, roasting is done by placing the maize on a glowing charcoal with the maize itself separated from the charcoal by a metal grill. The maize to be roasted is placed on a glowing charcoal and then turned occasionally to allow even distribution of heat. The charcoal is placed inside a tray and a metal grill is placed on top of the tray mainly to separate the maize to be roasted and the charcoal. To maintain the charcoal from glowing, a hand fan is used to blow air which support combustion. The faster the hand fan blow the faster the air current, the faster the rate of combustion and the rate of heat transfer from the charcoal to the maize. By convection, the heat is transferred to the maize on the metal grill. The process highlighted becomes strenuous as the operator tired out with time before the maize is completely roasted. The direct contact and exposure of the human body to direct heat emitted from the charcoal may have some damaging effect on the skin and some organ in the body. There is, therefore, a need to come up with a 
machine which reduces human labour and produces maximum roasting efficiency. The objective of this study was to develop a maize roaster with treadle drive blower and evaluated its performance using charcoal tray with different pattern of air flow duct.

\section{Material and Methods}

The analytical aspect in the design is to determine reliable parameters by which the system is developed to achieve safe and reliable operations while achieving the design objective. The details analyses of each section in the logical sequence of development are presented below. Machine element was designed base on belt design, shaft design and bearing selection design.

\subsection{Belt Design}

Speed ratio between driving and driven sleeves is 1:9 equation (1) is used to determine the tension on the belt and equation (2) is used to determine the power transmitted 4.

$$
\begin{gathered}
\mathrm{T}_{1} / \mathrm{T}_{2}=\mathrm{e}^{(\mu \theta)} \\
\mathrm{P}(\mathrm{w})=\left(\mathrm{T}_{1}-\mathrm{T}_{2}\right) \mathrm{V}_{\mathrm{b}}
\end{gathered}
$$

Where,

$\mathrm{T}_{1}$ - tension in slack side of the belt $(\mathrm{N})$,

$\mathrm{T}_{2}$ - tension at the tight side of the belt $(\mathrm{N})$

$\mu$ - coefficient of friction, $\theta$ - angle of lap and $V_{b}$ - speed of the driver $(\mathrm{m} / \mathrm{s})$

\subsection{Shaft Design}

The write the full meaningAmerican society of Mechanical Engineering (ASME) code Equation (3) for solid shaft combine torsion bending and axial load was used to determine the minimum diameter of the shaft used in the design[5].

$\mathrm{d}_{\mathrm{o}}{ }^{3}=\frac{16}{(\pi \tau)} \sqrt{\left(\mathrm{k}_{\mathrm{b}} \mathrm{M}_{\mathrm{b}}\right)^{2}+\left(\mathrm{K}_{\mathrm{t}} \mathrm{T}_{\mathrm{t}}\right)^{2}}$ (Budynas-Nisbett, 2006)

Where,

$\mathrm{d}_{\mathrm{o}}$ - diameter of shaft

$\mathrm{K}_{\mathrm{b}}$ - sock and fatigue stress concentration as apply to bending moment

$\mathrm{M}_{\mathrm{b}}$ - bending moment

$\mathrm{K}_{\mathrm{t}}$ - sock and fatigue moment as apply to torsional moment

$\mathrm{T}_{\mathrm{t}}-$ torsional moment

$\tau-$ shear stress

\subsection{Bearing Selection Design}

The bearing selection design was determine from the life equation and the type of loading the bearing is expected to carry.

The relationship between the basic rating life, the dynamic load rating and the bearing is express in Equation (4).

$$
\mathrm{L}_{10}=\left(\mathrm{C} / \mathrm{P}_{\mathrm{c}}\right)^{\mathrm{P}} \quad(\text { Budynas}- \text { Nisbett, 2006) }
$$

Where $\mathrm{L}_{10}$ is basic rating life in million of revolution, $\mathrm{c}$ is basic dynamic load rating, $P_{c}$ is equivalent dynamic bearing load $(\mathrm{N}), \mathrm{P}$ is exponent for the life equation

$$
\mathrm{P}=\mathrm{XF}_{\mathrm{r}}+\mathrm{YF}_{\mathrm{a}} \quad \text { (Budynas-Nisbett, 2006) }
$$

$F_{r}$ is actual radial bearing load and $F_{a}$ is axial radial bearing $(\mathrm{N})$

$\mathrm{X}$ - radial load factor for the bearing.

$\mathrm{Y}-$ axial load factor for the bearing.

\subsection{Material Selection Design}

The selection of suitable material for use after careful analysis and design consideration is based on various properties of engineering material such as strength, hardness ductility machinability and dimensional stability at high temperature (creep).

\subsection{Operation and Constructional Features}

The machine was conceptualized, designed and constructed. It consist of the following components:

(a) Frame: The frame is the machine structure, which gives support for the entire machine. It is made of angle iron and frame as specified in the working diagram

(b) Fan and Fan housing: The fan is made from a sheet metal and a shaft supported by a journal bearing. The sheet metal serves as the fan blade while the housing is made to aspirate air and built up pressure toward the discharge end. It is made of sheet metal as specified in the working diagram fig. (6)

(c) Treadle drive mechanism: These consist of a slider crank mechanism which rotate the pulley and transmits power to the blower via belt drive. The speed ratio is 1: 9, this means one rotation of the crank result in 9 rotation of the blower.

(d) Charcoal Tray: The charcoal trays are made from mild steel to accommodate charcoal that can roast maize conveniently and air flow from the fan. Four trays were constructed for performance test based on the pattern of air flow duct as specified in the working diagram and are shown in fig.(2) - fig. (5). A metal grill is attached to the tray as a means of separating the maize from the glowing charcoal.

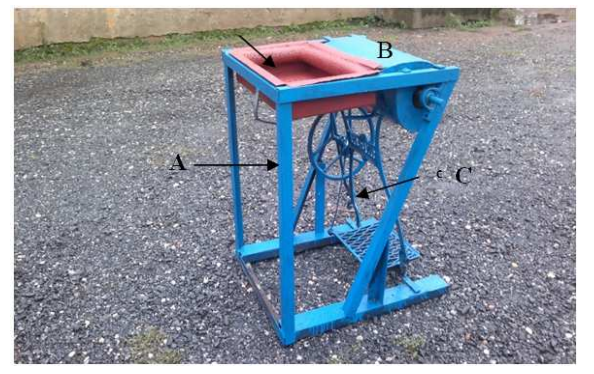

Fig 1. Maize Roasting Machine with Treadle Drive Blower. 
A. Frame

B. Fan and Fan Housing

C. Treadle Drive Mechanism

D. Charcoal Tray

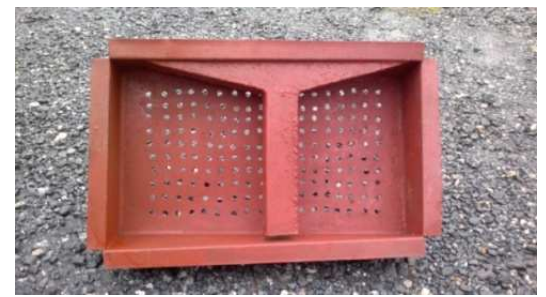

Fig 2. Tray with single face cone shape air

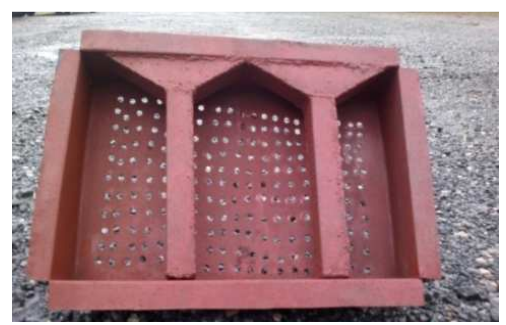

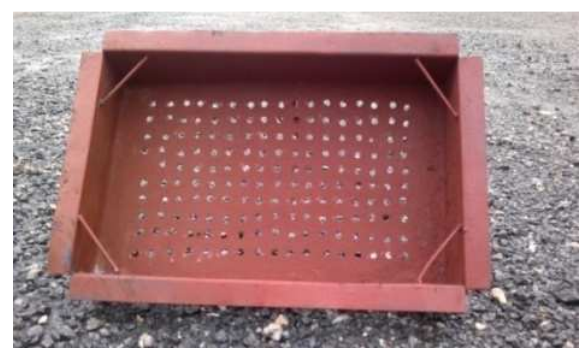

Fig 4. Tray with direct face air flow duct

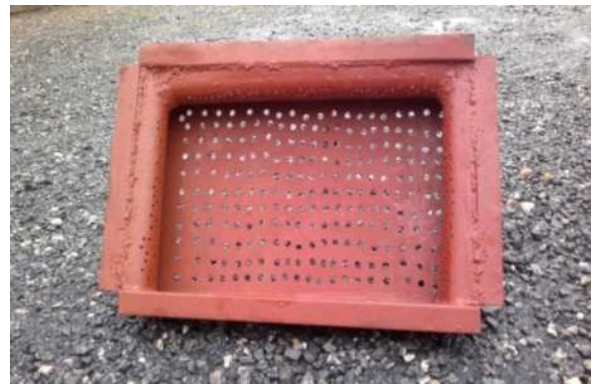

Fig 5. Tray with semi circular pipe shape air flow duct.

Fig 3. Tray with double cone shape air flow

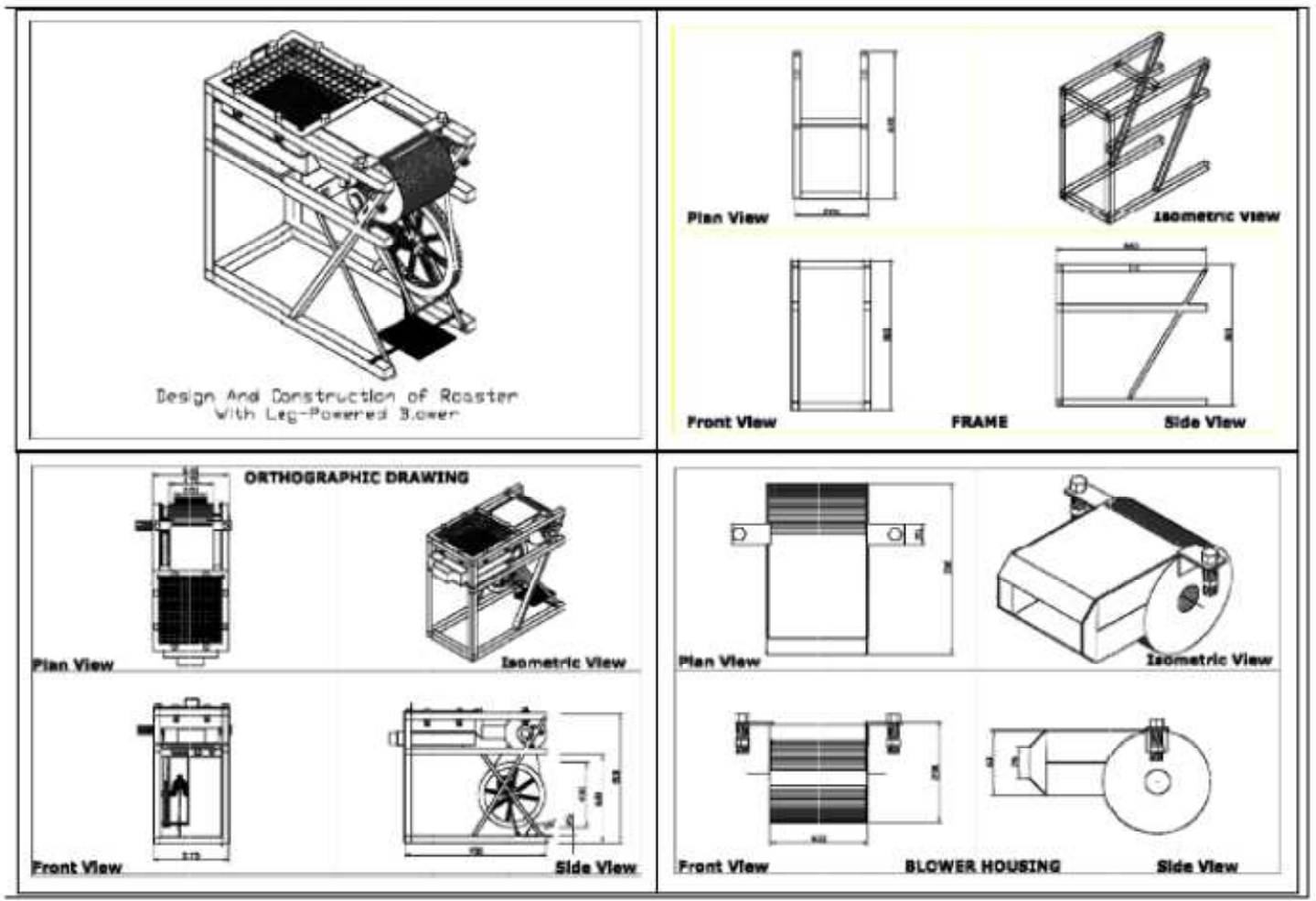

Fig 6. Working diagram for the construction of the maize roaster

\subsection{Performance Evaluation}

The performance of the machine was carried out by observing the time of roasting of known mass of maize using the four types of charcoal tray. The charcoal used for the roasting was weighted before initiating combustion which is sustained by the fan driven by the treadle, and then weighed after roasting. Bulk samples of maize cob were randomly selected and weighted then labeled as MA (mass
$120 \mathrm{~g}$ ), MB (mass $150 \mathrm{~g}$ ), MC (mass $170 \mathrm{~g}$ ) and MD (mass $190 \mathrm{~g}$ ) and each of the samples were roasted on the machine using different charcoal tray. Roasting was done by means of the treadle drive mechanism which drives the blower that support combustion of the charcoal in the tray and by manually turning each maize in the sample on the grill on the charcoal tray, roasted maize were judge by physical examination. The time taken to roast (in seconds) 
was recorded using a digital stop watch. The experiment was replicated three times. The evaluation method employed in analysis of the efficiency of the machine includes: the experimental design i.e completely randomized design and the mean separation i.e. Duncan multiple range test.

\section{Results and Discussion}

Table 1 presents the design details of the maize roaster with treadle drive blower upon which the machine was constructed. The diameter of shaft that was use for the blower fan is $20 \mathrm{~mm}$ which is in line with the design specification. The $321 \mathrm{~mm}$ is the average length of measured feet of 30 randomly selected adult operators specified for slider length as obtained in a preliminary investigation. The working diagram with dimension specifications used in the fabrication of the maize roasting machine is shown in Figure 6. The machine was tested on no-load to ensure rigidity of the fabricated part.

The average time taken to roast each sample (named the trays after these: MA, MB, MC and MD) of maize on the four types of trays are presented in Table 2 and a complete randomized design (CRD) was used to analyze variation in the average time of time of roasting on the four trays. As the mass increased, the time taken for roasting also increase this is due to the fact that the convective heat transfer to the maize decrease with surface area tray 4 (tray with). The analysis of variance of the efficiency of four charcoal trays is presented in Table 4. There is a significant different ( $p<$ 0.05 ) in the time of roasting of the maize sample on the trays this can be seen from the ANOVA table.

Table 1. Design details of machine element for maize roaster

\begin{tabular}{ll}
\hline Determined Parameters & Calculated Value \\
\hline Tension in slack side of belt $(\mathrm{N})$ & 291 \\
Tension in the tight side of belt $(\mathrm{N})$ & 500 \\
Velocity of crank $(\mathrm{m} / \mathrm{s})$ & 24 \\
Power required $(\mathrm{W})$ & 1182 \\
Length of slider $(\mathrm{m})$ & 321 \\
Torgue on shaft $(\mathrm{Nm})$ & 150 \\
Diameter of shaft $(\mathrm{mm})$ & 22.97 \\
Factor of safety & 2 \\
Bearing design life $(\mathrm{rmp})$ & $1.2 \times 10^{7}$ \\
Bearing design load $(\mathrm{N})$ & 212 \\
Basic dynamic rating $(\mathrm{N})$ & 490 \\
Basic working life $(\mathrm{hr})$ & $12.6 \times 10^{7}$ \\
\hline
\end{tabular}

Table 4 present the mean separation table, using Duncan multiple range test, which shows the range at which different trays performance under the machine at a particular time of roasting. Tray 4 has the lowest mean separation of 499.83 , closely followed by tray 3 , tray 2 , and tray 1 respectively. There is no significant difference in the mean separation of tray 3 and tray 4 . This shows that the tray with lowest mean separation have the highest value of efficiency to roast within a short period of time.
Table 2. Time of roasting on different Trays

\begin{tabular}{lllll}
\hline \multicolumn{5}{l}{ Time of roasting (s) } \\
\hline Charcoal trays & MA & MB & MC & MD \\
\hline Tray 1 & 525 & 495.66 & 541.67 & 584.67 \\
Tray 2 & 681.33 & 697.00 & 673.67 & 726.33 \\
Tray 3 & 534.32 & 479.00 & 480.66 & 505.33 \\
Tray 4 & 566.67 & 554.66 & 556.33 & 534.67 \\
\hline
\end{tabular}

Table 3. Analysis of variance of the efficiency of different charcoal tray source.

\begin{tabular}{|c|c|c|c|c|}
\hline Source of variation & $\begin{array}{l}\text { D. } \\
\text { F }\end{array}$ & S.S & MSS & F Calculated \\
\hline Mass & 3 & 7021.06 & 2340.35 & 1.42 \\
\hline Treatment & 3 & 261979.06 & 87326.35 & 52.98 \\
\hline Treatment* mass & 9 & 17974.02 & 1997.11 & 1.21 \\
\hline
\end{tabular}

Where, D.F Degree of freedom, S.S sum of squares M.SS mean sum of square.

Table 4. Mean separation-using Duncan multiple range Test

\begin{tabular}{ll}
\hline Treatment & Mean \\
\hline 1 & $694.58^{\mathrm{a}}$ \\
2 & $553.08^{\mathrm{b}}$ \\
3 & $536.75^{\mathrm{b}}$ \\
4 & $499.83^{\mathrm{c}}$ \\
\hline
\end{tabular}

Mean with the same letter are not significantly difference

\section{Conclusions}

A machine for roasting of maize has been developed. The machine has shown to be a simple to operate and maintained without the need for special training, thus, the operation and maintenance of the machine performance and compactness will make it acceptable and adaptable to the small or medium scale industry for maize.

\section{Acknowledgments}

The authors acknowledge the assistance of Messrs, Babalola O.A, Oladimeji, D. A., Popoola, O.A and Ganiyu, A.A. in carrying out the study

\section{References}

[1] Ayatse, J. O, Eka, O.U and Ifon, E.T (1983). Chemical evaluation of the effect of roasting on the nutritive value of maize (Zea mays, linn). Food chemistry Vol. 12 No 2 pp 135 $-147$

[2] Kolawole, S. O (1997). Traditional Preparation and uses of maize in Nigeria. retrieved Dec 22, 2006. from http:siuedu.nabl./articles:-html

[3] www.wikipedia (the free encyclopedia 2006) Roasting methods of some selected foods product retrieved October 31,2006 .

[4] Srinivas, J, 2004. Handbook of Mechanical Engineering. New Delhi; Laxmi Publication Ltd. 